Article

\title{
Effect of Candida intermedia LAMAP1790 Antimicrobial Peptides against Wine-Spoilage Yeasts Brettanomyces bruxellensis and Pichia guilliermondii
}

\author{
Rubén Peña ${ }^{\circledR}$, Jeniffer Vílches, Camila G.-Poblete and María Angélica Ganga * \\ Laboratorio de Biotecnología y Microbiología Aplicada, Departamento de Ciencia y Tecnología de los Alimentos, \\ Universidad de Santiago de Chile, Santiago 917020, Chile; ruben.pena@usach.cl (R.P.); \\ jeniffernatalia221@gmail.com (J.V.); camila.gonzalezpo@usach.cl (C.G.-P.) \\ * Correspondence: angelica.ganga@usach.cl; Tel.: +56-2-27184509
}

Received: 25 May 2020; Accepted: 19 June 2020; Published: 1 July 2020

check for updates

\begin{abstract}
Wine spoilage yeasts are one of the main issues in the winemaking industry, and the control of the Brettanomyces and Pichia genus is an important goal to reduce economic loses from undesired aromatic profiles. Previous studies have demonstrated that Candida intermedia LAMAP1790 produces antimicrobial peptides of molecular mass under $10 \mathrm{kDa}$ with fungicide activity against Brettanomyces bruxellensis, without affecting the yeast Saccharomyces cerevisiae. So far, it has not been determined whether these peptides show biocontroller effect in this yeast or other spoilage yeasts, such as Pichia guilliermondii. In this work, we determined that the exposure of B. bruxellensis to the low-mass peptides contained in the culture supernatant of $C$. intermedia LAMAP1790 produces a continuous rise of reactive oxygen species (ROS) in this yeast, without presenting a significant effect on membrane damage. These observations can give an approach to the antifungal mechanism. In addition, we described a fungicide activity of these peptides fraction against two strains of P. guilliermondii in a laboratory medium. However, carrying out assays on synthetic must, peptides must show an effect on the growth of B. bruxellensis. Moreover, these results can be considered as a start to develop new strategies for the biocontrol of spoilage yeast.
\end{abstract}

Keywords: antimicrobial peptides; Brettanomyces bruxellensis; Candida intermedia; Pichia guilliermondii; reactive oxygen species

\section{Introduction}

Alcoholic fermentation is the process of monosaccharide's conversion to ethanol and $\mathrm{CO}_{2}$. Therefore, the anaerobic metabolism of Saccharomyces cerevisiae is the main cause of wine fermentation. However, in spontaneous wine production other yeasts participate such as Hanseniaspora, Candida, Pichia, and Metschnikowia genera, among others [1]. Nevertheless, these yeasts have lower fermentation capacity, and are not able to grow in high ethanol concentration conditions, given that the Saccharomyces genus is the predominant during the final stages of fermentation [1].

Among the unfavorable growth wine conditions, several yeasts are capable to proliferate and generate undesired characteristics in the final product. Brettanomyces bruxellensis has been described as the main spoilage yeast during the maturity stage of wine in barrels [2,3]. This yeast has the capacity of transforming hydroxycinnamic acids into vinyl and ethyl derivates, which produce off-flavors in wine [4,5]. Additionally, this aromatic defect can be produced in early stages of fermentation by other yeasts such as Pichia guilliermondii [2]. Among these, there are strains which can transform $p$-coumaric acid in 4-vinylphenol in similar proportions as described for B. bruxellensis, being that P. guilliermondii is a potential problem for winemaking [6]. Because of this, in this industry the use of 
sulfites is a widespread strategy to control growth of undesired microorganisms. Nevertheless, several strains are resistant and the use of sulfites in high quantities is potentially unsafe for human health [7]. As a result, alternative strategies such as antimicrobial peptides (AMPs) have been proposed to biocontrol spoilage microorganisms [8-12]. AMPs are low molecular mass peptides with amphipathic characteristic which can affect the growth of several microorganisms by permeabilization of plasmatic membranes and/or by increasing the reactive oxygen species [13-15]. Previously, Peña et al. [16,17] have described antimicrobial peptides production in Candida intermedia, which reduce the viability of different B. bruxellensis strains in a laboratory medium without affecting the growth of fermentative yeast S. cerevisiae. However, it has not yet been described how these peptides affect B. bruxellensis and if they are able to inhibit the growth of P. guilliemondii. Thus, the aim of this work was to explore the cellular damage produced by $C$. intermedia LAMAP1790 peptides above B. bruxellensis and determine if they can control the growth of yeast B. bruxellensis and P. guilliermondii using laboratory culture mediums and synthetic must. This knowledge will allow to determine the antimicrobial peptides produced for $C$. intermedia as a possible biocontroller in the wine industry.

\section{Materials and Methods}

\subsection{Strains and Culture Media}

The strains of B. bruxellensis LAMAP2480, C. intermedia LAMAP1790, Pichia guilliermondii LAMAP3202, LAMAP3203, S. cerevisiae BY4741, and EC1118 were obtained from the culture collection at the Laboratory of Biotechnology and Applied Microbiology, University of Santiago de Chile. C. intermedia LAMAP1790 was isolated in Chile from must in the early stages of fermentative process [18] and B. bruxellensis LAMAP2480 was isolated from Chilean wine [19]. Both strains of P. guilliermondii were isolated from Argentinian vineyards. The strain LAMAP3202 and LAMAP3203 was characterized by Sangorrín et al. (2013), labeled as P7 and P8 strains respectively [20]. All strains used in this work were grown on GYEB media (yeast extract $5 \mathrm{~g} / \mathrm{L}$ and glucose $20 \mathrm{~g} / \mathrm{L}$, adjusted to pH 5.0 with $100 \mathrm{mmol} / \mathrm{L}$ phosphate-citrate buffer) [21].

\subsection{Obtained Supernatant with Antifungal Activity of C. intermedia and Characterization of the Protein Nature of This Activity}

To obtain the supernatant with antifungal activity from C. intermedia LAMAP1790, the yeast was inoculated in $100 \mathrm{~mL}$ GYEB medium during $48 \mathrm{~h}$ at $28{ }^{\circ} \mathrm{C}$ with orbital agitation at $120 \mathrm{rpm}$. Then, the culture was centrifuged during $10 \mathrm{~min}$ at $5900 \times g$ to obtain saturated culture supernatant. Afterward, a cut-off of total proteins present in the supernatant was done by means of ultrafiltration in devises Amicon ${ }^{\circledR}$ Ultra-15 with 10 kDa cutoff (Merck-Millipore ${ }^{\circledR}$, Darmstadt, Germany). In this work, the antifungal supernatant is defined as the fraction obtained from ultrafiltration which only contains proteins of molecular mass under $10 \mathrm{kDa}$. This antifungal supernatant was sterilized using disposable filters with $0.22 \mu \mathrm{m}$ pore size (Membrane Solutions LLC ${ }^{\circledR}$, Windham, NH, USA) and stored at $-20^{\circ} \mathrm{C}$ to be used later. To determine whether the antifungal activity is related with the presence of peptides with molecular mass under $10 \mathrm{kDa}$, the antifungal supernatant was treated with $2 \mathrm{mg} / \mathrm{mL}$ protease of Streptomyces griseus (Sigma-Aldrich ${ }^{\circledR}$, St. Louis, MO, USA) during 4 h at $37^{\circ} \mathrm{C}$.

2.3. Determination of the Cellular Damage Produced on B. bruxellensis by Exposure to Antifungal Supernatant of C. intermedia

The obtained antifungal supernatant of C. intermedia LAMAP1790 was assessed to determine if it produces: (a) membrane permeability or (b) rise of the reactive oxygen species (ROS) on exposed B. bruxellensis cells during different periods, similar to described by [22] and [23]. Then, $3 \times 10^{5}$ B. bruxellensis LAMAP2480 cells were exposed individually to $1 \mathrm{~mL}$ of sterile antifungal supernatant and incubated during $12 \mathrm{~h}$ and $24 \mathrm{~h}$ at $28{ }^{\circ} \mathrm{C}$. As positive control, a similar number of cells with $600 \mu \mathrm{g} / \mathrm{mL}$ zymolyase $100 \mathrm{~T}$ (Amsbio ${ }^{\circledR}$, Abingdon, OX, UK) was inoculated at $37^{\circ} \mathrm{C}$ during $2 \mathrm{~h}$ and 
then exposed to $30 \% \mathrm{H}_{2} \mathrm{O}_{2}$ during $30 \mathrm{~min}$. As negative control, the same concentration of cells was used and at $28^{\circ} \mathrm{C}$ in buffer HEPES saline $1 \times \mathrm{pH} 7.0\left(70 \mathrm{mM} \mathrm{NaCl}, 0.75 \mathrm{mM} \mathrm{Na}_{2} \mathrm{HPO}_{4}, 25 \mathrm{mM} \mathrm{HEPES}\right)$ were incubated. After treatments, the cells were washed 3 times with buffer HEPES saline $1 \times \mathrm{pH} 7.0$. To facilitate the observation, yeast was stained with calcofluor white (Sigma ${ }^{\circledR}$ ) in 1:1 proportion with $\mathrm{KOH}$ to $10 \% \mathrm{p} / \mathrm{v}$. The membrane permeability was assessed by means of staining with $2 \mu \mathrm{M}$ propidium iodide (Sigma ${ }^{\circledR}$ ) and the accumulation of ROS was determined by means of staining with $10 \mu \mathrm{M}$ 6-carboxy-2' $7^{\prime}$-dichlorodihydrofluorescein diacetate (C400; Thermo-Scientific ${ }^{\circledR}$, Waltham, MA, USA). The fluorescent cells were observed using the epifluorescence microscope Moticam Pro BA410 (Motic ${ }^{\circledR}$, Xiamen, China), with $40 \times$ fluorescence microscope objective lent.

2.4. Screening the Antifungal Activity of C. intermedia LAMAP1790 on B. bruxellensis, P. guilliermondii, and S. cerevisiae

The qualitative determination of the antifungal activity of $C$. intermedia LAMAP1790 on B. bruxellensis LAMAP2480, P. guilliermondii LAMAP3203, LAMAP3203 and S. cerevisiae EC1118 strains was carried out following the methodology used by [16]. For this, $1 \times 10^{5}$ cells from each strain were inoculated in $25 \mathrm{~mL}$ warm agar MBA ( $5 \mathrm{~g} / \mathrm{L}$ yeast extract, $5 \mathrm{~g} / \mathrm{L}$ peptone, $20 \mathrm{~g} / \mathrm{L}$ glucose and $15 \mathrm{~g} / \mathrm{L}$ agar, adjusted to $\mathrm{pH} 5.0$ with $100 \mathrm{mmol} / \mathrm{L}$ phosphate-citrate buffer and supplemented with $0.03 \mathrm{~g} / \mathrm{L}$ of methylene blue). Each inoculated media was plated into petri dishes. A surface inoculation was carried out using $10 \mu \mathrm{L}$ of $1 \times 10^{8}$ cells/mL suspension from C. intermedia LAMAP1790. As control, the same surface inoculation of $S$. cerevisiae BY4741 was carried out. The plates were incubated for 7 days at $28^{\circ} \mathrm{C}$ and every assay was evaluated six times. The qualitative determination was done by observation and measuring the inhibition halo present in the plates.

2.5. Antifungal Activity of Low Mass Peptide Fraction Obtained from C. intermedia Antifungal Supernatant against B. bruxellensis, S. cerevisiae and P. guilliermondii in Synthetic Must

The obtention of 100X concentrated low mass peptide fraction (under $10 \mathrm{kDa}$ ) was performed by lyophilization (IlShineBioBase ${ }^{\circledR}$ freeze dryer, Dongducheon-si, Gyeonggi-do, Korea) of 3 L to sterile antifungal supernatant derived from cultures of $C$. intermedia LAMAP1790 in GYEB medium. The total protein quantification in the fraction was done according to [24]. The evaluation of the antifungal activity was done using simultaneous inoculation of S. cerevisiae EC1118 and B. bruxellensis LAMAP2480 or P. guilliermondii LAMAP3202 in synthetic grape must, (100 g/L glucose, $100 \mathrm{~g} / \mathrm{L}$ fructose, $5 \mathrm{~g} / \mathrm{L}$ maleic acid, $0.5 \mathrm{~g} / \mathrm{L}$ citric acid, $3 \mathrm{~g} / \mathrm{L}$ tartaric acid, $0.75 \mathrm{~g} / \mathrm{L}$ potassium phosphate, $0.5 \mathrm{~g} / \mathrm{L}$ potassium sulfate, $0.155 \mathrm{~g} / \mathrm{L}$ calcium chloride, $0.25 \mathrm{~g} / \mathrm{L}$ magnesium sulfate, $0.2 \mathrm{~g} / \mathrm{L}$ sodium chloride, $4 \mathrm{mg} / \mathrm{L}$ manganese sulfate, $1.5 \mathrm{mg} / \mathrm{L}$ calcium pantenoate, $2 \mathrm{mg} / \mathrm{L}$ nicotinic acid, $0.25 \mathrm{mg} / \mathrm{L}$ thiamine hydrochloride and $0.003 \mathrm{mg} / \mathrm{L}$ biotin; $\mathrm{pH}$ 3.5) [25], Previously, each strain was adapted to the media using a procedure described by [26]. To the antifungal assays, $5 \mathrm{~mL}$ synthetic must was inoculated with $1 \times 10^{2}$ cells of S. cerevisiae EC1118, B. bruxellensis LAMAP2480 or P. guilliermondii LAMAP3202 strains individually (determined by direct yeast count in Neubauer chamber), and supplemented with $1 \mu \mathrm{g}$ of low mass peptide fraction. As a control, the same procedure was carried out, but the medium was supplemented with $1 \mu \mathrm{g}$ of total proteins obtained from the concentrate sterile culture supernatant of $S$. cerevisiae BY4741 (IlShineBioBase ${ }^{\circledR}$ freeze dryer, Dongducheon-si, Gyeonggi-do, Korea). Each assay was incubated for 21 days, and every 3 days a cellular count of the cultures was carried out on YPD agar plates $(5 \mathrm{~g} / \mathrm{L}$ yeast extract, $5 \mathrm{~g} / \mathrm{L}$ peptone, $20 \mathrm{~g} / \mathrm{L}$ glucose and $20 \mathrm{~g} / \mathrm{L}$ agar) incubated for 7 days at $28^{\circ} \mathrm{C}$. The count of spoilage yeast in the mixed culture was performed in YPD agar plates supplemented with $0.01 \% v / v$ of cycloheximide, according to [27].

\subsection{Statistical Analysis}

All the data was analyzed using the Kruskal-Wallis test, with an initial analysis of the distribution goodness of fit using the Kolmogorov-Smirnov test. All analysis was carried out with Statgraphics 
Centurion XVI Software (Statpoint Technologies Inc., Warrenton, VA, USA). The significant differences were validated with a probability $<0.05$.

\section{Results and Discussion}

One of the most important aspects in the study of AMPs is to determine its antifungal action mechanism. In relation to antimicrobial peptides to biocontrol contaminant microorganisms in winemaking, Enrique et al. (2008) [9] studied the antifungal effect of the synthetic peptide LfcinB $_{17-31}$ on B. bruxellensis, determining that its action mechanism is related to the penetration of the peptides into the cell cytoplasm. Additionally, by fluorescence microscopy, Branco et al. (2017) [12] have described that saccharomycin (antifungal peptides produced by S. cerevisiae CCMI885 strain) produce cell membrane disruption and internalization of the peptides in Hanseniaspora guilliermondii and B. bruxellensis. Our previous results have demonstrated that $C$. intermedia LAMAP1790 releases peptides in the culture medium with masses under $4.6 \mathrm{kDa}$, which show selective antifungal activity on $B$. bruxellensis strains $[16,17]$. With the purpose of defining the cell damaged produced by the antifungal supernatant of $C$. intermedia LAMAP1790 (which contains these peptides) on B. bruxellensis LAMAP2480, different assays were carried out using calcofluor white (CW), propidium iodide (PI), or 6-carboxy-2', $7^{\prime}$-dichlorodihydrofluorescein diacetate (C400) [12,22,28] (Figure 1).

Under optimum growth condition, the yeast wall stains bright blue-white by the CW assembly [28], being impermeable to PI [12] and the C400 cannot be oxidized to its fluorescence form [22]. As a negative control, cells were inoculated in buffer HEPES saline pH 7.0 (Figure 1A-C), it can be observed that neither the wall cellular nor the impermeability of the membrane was affected. Only $29.91 \pm 7.29 \%$ of the observed cells in the medium show green fluorescence (Figure 1C) and none show red color. This increase of green fluorescence would be related to the lack of nutrients that B. bruxellensis had during the $24 \mathrm{~h}$ trail, due has been reported that such periods may activate an autophagy process $[29,30]$. Autophagy is a non-selective degradation of organelles or intracellular macromolecules, a recycling process that allows the amino acid supply and survival. S. cerevisiae can do mitophagy (removal of damaged mitochondria), therefore, releasing mitochondrial ROS into the cytoplasm $[29,30]$. On the other hand, when the cells have damage in the membrane, this is no longer impermeable to PI, dying cells in red [23].

Thus, as a positive control of both processes, we carried out an induction to the oxidative stress and membrane damage by zymolyase and $\mathrm{H}_{2} \mathrm{O}_{2}$ treatment (Figure 1D-F). As observed in this figure the treatment produced a $63.39 \pm 6.92 \%$ permeabilization to cell surface membrane, allowing the penetration of PI into the cell (compared with control sample 1B). Besides, a $63.61 \pm 8.17 \%$ of cells show a rise of intracellular ROS, which allowed the observation of green fluorescence derived from C400 oxidation (Figure 1F). Additionally, when yeasts were exposed to C. intermedia supernatant at $12 \mathrm{~h}$, it was observed a rise in the number of cells which oxide C400 (Figure 1I) which is sustained at $24 \mathrm{~h}$ of incubation (Figure 1L), while it is observed a little rise of permeable cells of PI to $24 \mathrm{~h}$ of incubation (Figure $1 \mathrm{H}, \mathrm{K}$ ). When the $\mathrm{C}$. intermedia supernatant is treated with protease, a decrease decrease in the number of cells that oxidize C400 and the permeable cells of PI (Figure 1N,O) was observed, confirming that antifungal compounds have protein nature [16].

By comparing the percentage of fluorescent yeast in different conditions (Figure 2), it can be observed that the incubation of B. bruxellensis with the antifungal supernatant produce a sustaining little rise in the number of permeable cells to PI at incubation time, is not statistically different from the negative control (Figure 2A). 


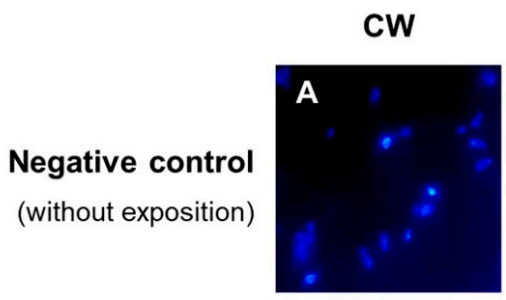

PI
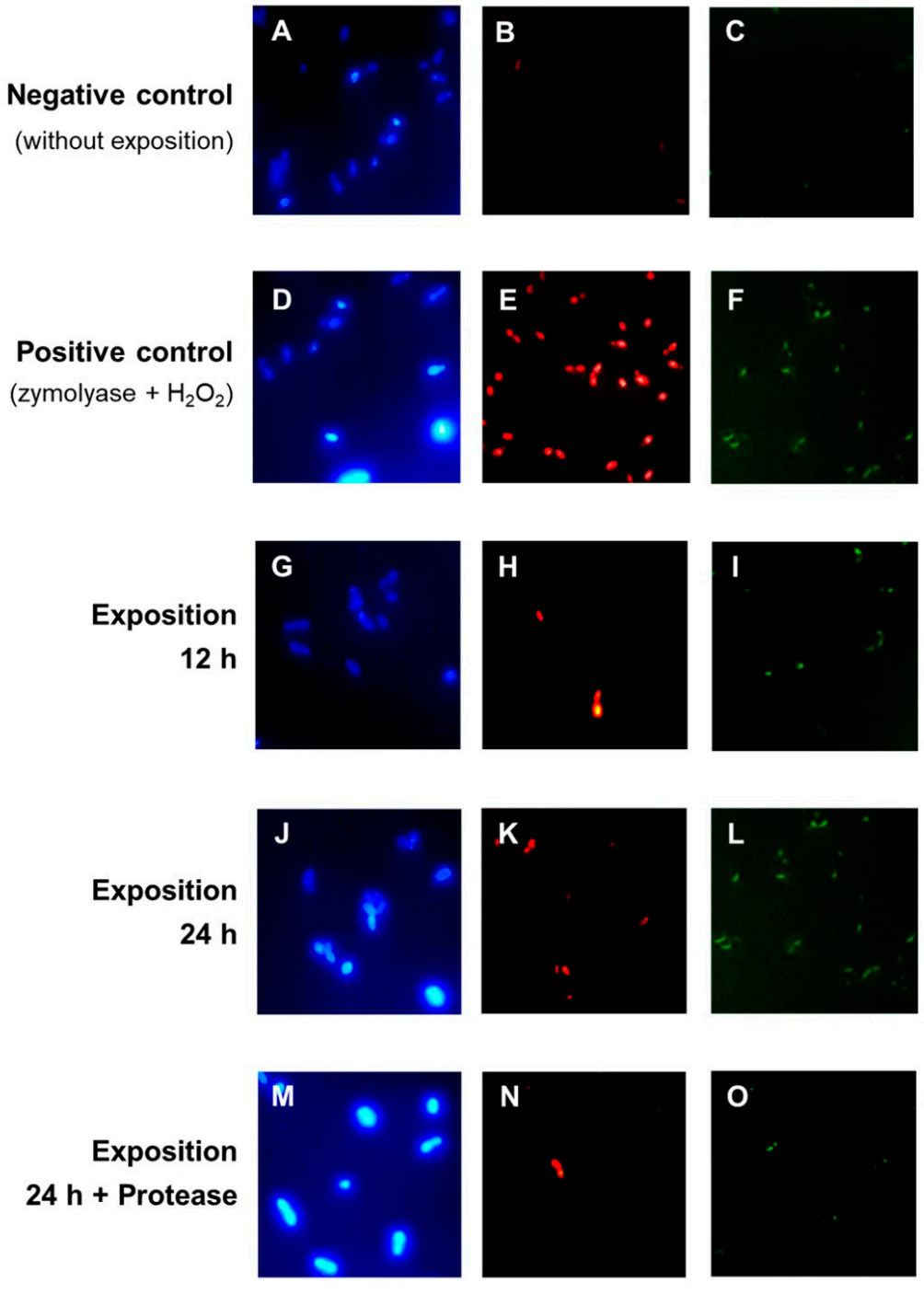
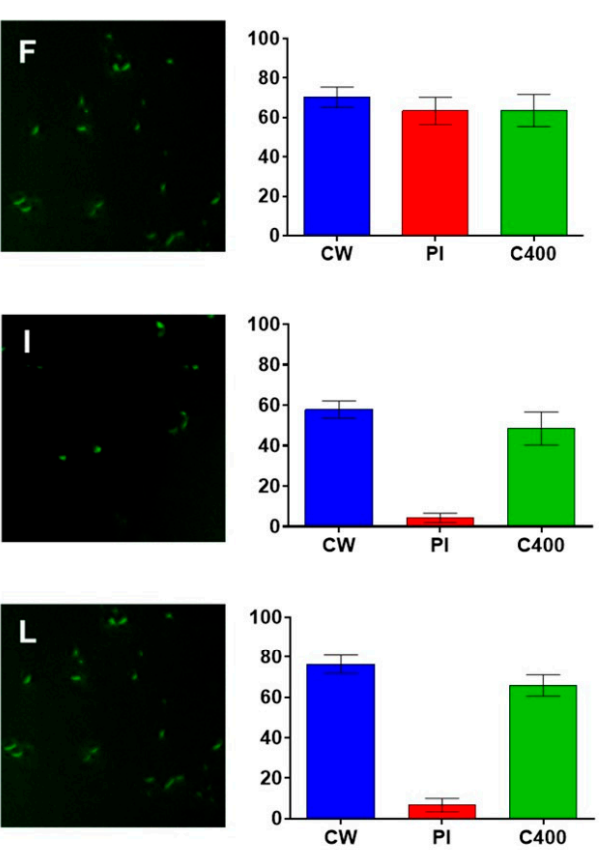

Fluorescents cells

(\% per field)
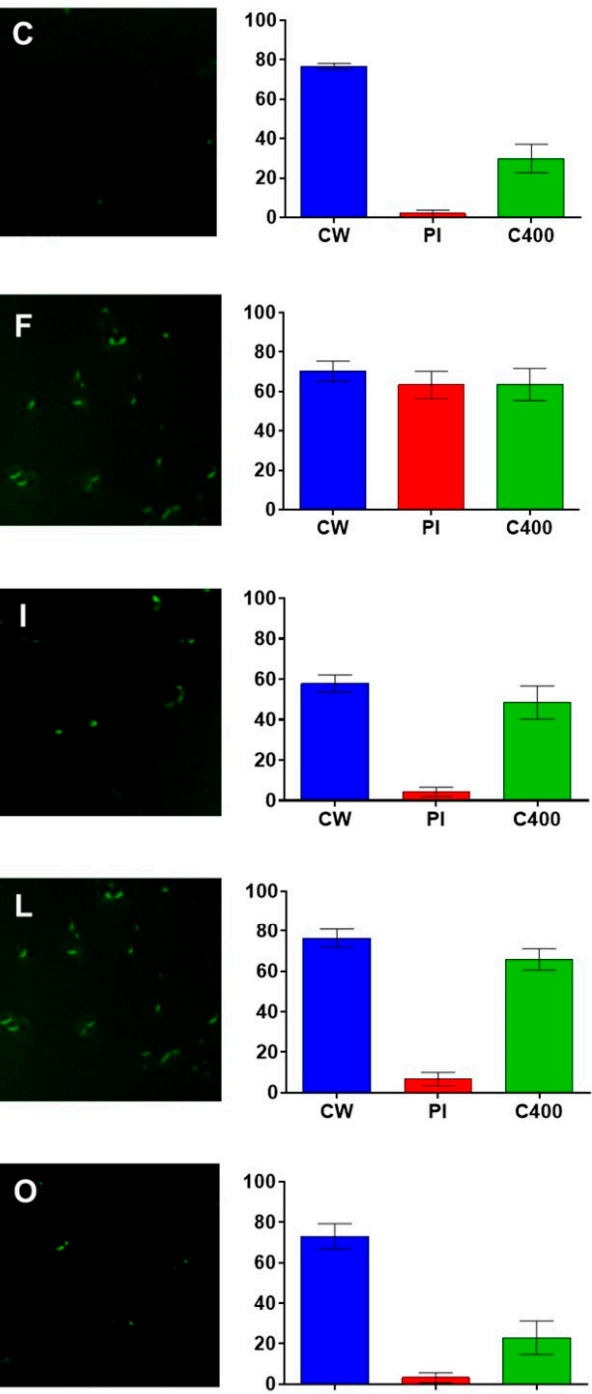

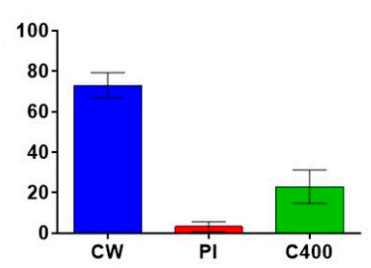

Figure 1. Evaluation of permeability and reactive oxygen species (ROS) accumulation in B. bruxellensis LAMAP2480 cells exposed to C. intermedia LAMAP1790 antifungal supernatant at different times, using epifluorescence microscopy. Graphics at the right side of each line represents a percentage of fluorescent cells per field counted in each treatment. (A-C): untreated yeasts (Negative control). (D-F): yeasts exposed to $\mathrm{H}_{2} \mathrm{O}_{2} 30 \% \mathrm{v} / \mathrm{v}$ for $30 \mathrm{~min}$, after treatment with zymolyase $(600 \mu \mathrm{g} / \mathrm{mL})$ for $2 \mathrm{~h}$ at $37^{\circ} \mathrm{C}$ (Positive control). (G-I): yeasts exposed to C. intermedia antifungal supernatant for $12 \mathrm{~h}$. (J-L): yeasts exposed to $C$. intermedia antifungal supernatant for $24 \mathrm{~h}$. (M-O): yeasts exposed to $C$. intermedia antifungal supernatant for $24 \mathrm{~h}$ after a proteolytic treatment to the supernatant for $4 \mathrm{~h}$ at $37^{\circ} \mathrm{C}$ with $2 \mathrm{mg} / \mathrm{mL}$ of Streptomyces griseus protease (Sigma $\left.{ }^{\circledR}\right)$. CW: calcofluor white staining, PI: propidium iodide staining, C400: 6-carboxy-2', $7^{\prime}$-dichlorodihydrofluorescein diacetate staining. 
A

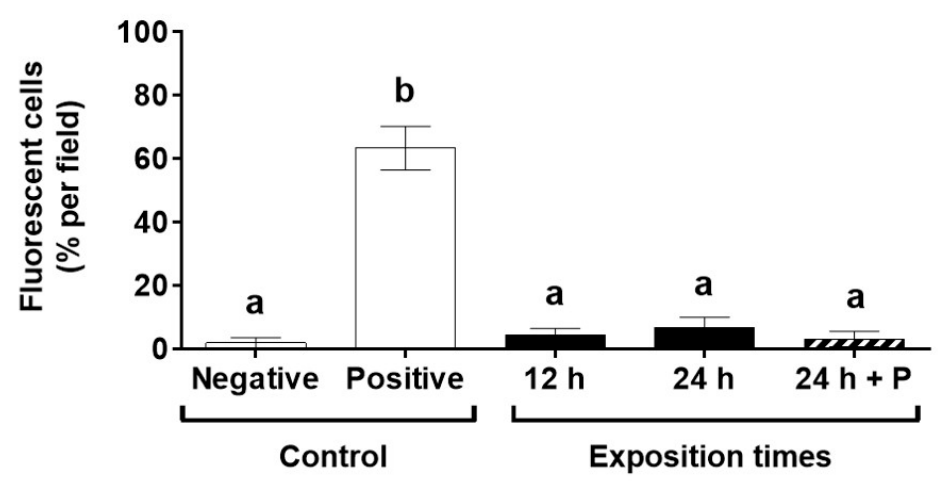

B

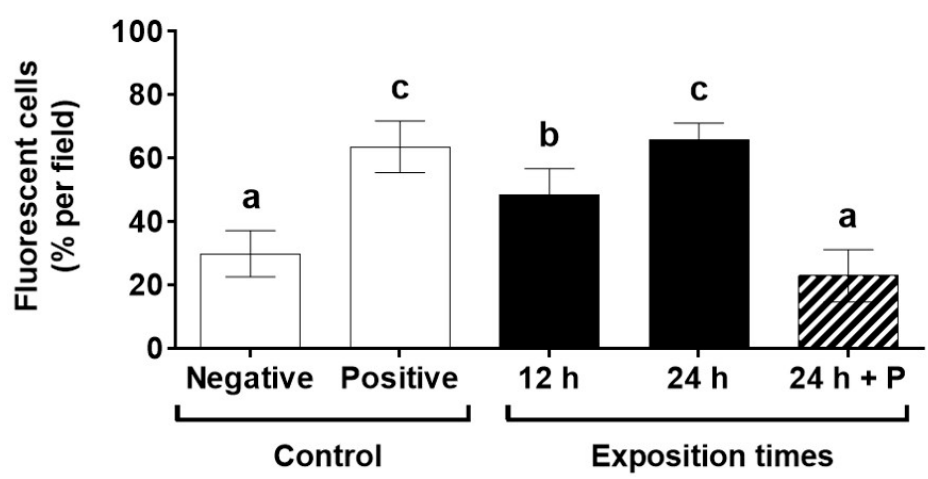

Figure 2. Evaluation of damage produced in B. bruxellensis cells after $12 \mathrm{~h}$ and $24 \mathrm{~h}$ of exposition to antifungal supernatant from C. intermedia LAMAP1790. (A): Membrane damage observed by cell permeability to propidium iodide staining, (B): Oxidative damage derived of ROS accumulation measured with 6-carboxy-2" ${ }^{\prime \prime} 7^{\prime}$-dichlorodihydrofluorescein diacetate staining. The evaluation was performed comparing the percentage of stained fluorescent cells of B. bruxellensis after each treatment. White bars correspond to control treatments, black bars correspond to yeasts exposed to antifungal supernatant at labeled times and bars in striped lines (labeled $24 \mathrm{~h}+\mathrm{P}$ ) correspond to $24 \mathrm{~h}$ of yeasts exposition to antifungal supernatant treated previously with $2 \mathrm{mg} / \mathrm{mL}$ of Streptomyces griseus protease $\left(\right.$ Sigma $\left.{ }^{\circledR}\right)$. Different letter above each column represents a significative difference $(p<0.05)$.

Nevertheless, by evaluating the percentage of cells which oxidize C400, they increase significantly as incubation time increases, even achieving similar values to the obtained due to the introduction to oxidative stress with $\mathrm{H}_{2} \mathrm{O}_{2}$ (Figure 2B). These results allow to demonstrate that the sustaining increase of ROS in B. bruxellensis is related to the presence of peptides of mass under $10 \mathrm{kDa}$ in the antifungal supernatant of $C$. intermedia LAMAP1790 and propose that its antifungal action mechanism would be related to the oxidative damage that the exposed cell suffers to the supernatant. This should be proved by the non-significant rise of the observed permeability to PI in B. bruxellensis between $12 \mathrm{~h}$ and $24 \mathrm{~h}$ of exposure to antifungal supernatant, because it has been demonstrated that the induction of ROS in yeasts such as $H$. guilliermondii produces the permeabilization of its cellular membrane [11]. Similar effects have been reported to synthetic peptide PAF26 and other similar peptides in which have been demonstrated that they can penetrate the cytoplasm of S. cerevisiae, without affecting firstly the integrity of the cellular membrane $[13,14,31]$. Thus, it determined that the synthetic peptide PAF26 would have a multistep mechanism of action, where it first interacts with the wall or cellular membrane, then it would be endocytosed and accumulated in the vacuoles, and finally, it would be transported to the 
cytoplasm and perform its antifungal action [14]. This mechanism would be like the observations made for B. bruxellensis by means of fluorescence microscopy.

It was carried out a qualitative antifungal test with S. cerevisiae, B. bruxellensis, and two strains of P. guilliermondii in solid MBA agar plates to determine the formation of inhibition halos produced by C. intermedia LAMAP1790. The two strains of P. guilliermondii selected was previously studied by Sangorrín et al. (2013) [20]. In that work, from a pool of 15 strains, it was possible to conclude that strains LAMAP3202 and LAMAP3203 (labeled by Sangorrín as P7 and P8) have the highest transformation efficiencies of $p$-coumaric acid in 4-vinylphenol (more aggressive wine-spoilage phenomena). For these reasons, we considered these strains as the best model to our study. As shown in Table 1, S. cerevisiae EC1118 strain does not show growth inhibition, while the B. bruxellensis LAMAP2480 strain shows a clear inhibition halo surrounding culture of $C$. intermedia, whose diameter reached $19.00 \pm 0.62 \mathrm{~mm}$, as it was described by Peña et al. [16,17]. By analyzing the behavior of P. guilliermondii, LAMAP3202 and LAMAP3203 strains can be observed that an inhibition halo appears, whose diameters reached $15.33 \pm 0.82 \mathrm{~mm}$ and $16.17 \pm 0.75 \mathrm{~mm}$, respectively (Table 1 ). Then, B. bruxellensis shows a greater sensitivity to the presence of $C$. intermedia than P. guilliermondii. Similar studies carried out by Lopes and Sangorrín (2010) [32] have demonstrated that P. guillermondii sensitivity depends on the yeast strains to which it is exposed. On the other hand, Villalba et al. (2016) [23] demonstrated that the production of antifungal compounds of protein nature produced by Torulaspora delbrueckii, which has a molecular mass above $30 \mathrm{kDa}$, shows glucanase and chitinase activity. Therefore, the authors conclude that this would be a killer toxin rather than an antimicrobial peptide (AMP). Thus, this work would constitute the first qualitative evidence which shows the sensitivity of P. guilliermondii strains to antimicrobial peptides produced by non-Saccharomyces yeasts.

Table 1. Inhibition halos obtained after the exposure of $C$. intermedia LAMAP1790 against strains of $S$. cerevisiae, B. bruxellensis and Pichia guilliermondii in MBA medium.

\begin{tabular}{ccc}
\hline & & $\begin{array}{c}\text { C. intermedia } \text { LAMAP1790 } \\
\text { Inhibition Halo (mm) }\end{array}$ \\
\hline S. cerevisiae & EC1118 & ${ }^{\dagger} \mathrm{ND}^{\mathrm{a}}$ \\
B. bruxellensis & LAMAP2480 & $19.00 \pm 0.62^{\mathrm{c}}$ \\
P. guilliermondii & LAMAP3202 & $15.33 \pm 0.82^{\mathrm{b}}$ \\
& LAMAP3203 & $16.17 \pm 0.75^{\mathrm{b}}$ \\
\hline
\end{tabular}

Values with the same superscript letter are not significantly different $(p<0.05) .{ }^{\dagger}$ ND: Non-Detected.

With the purpose of determining whether the antifungal effect of $C$. intermedia LAMAP1790 is similar in winemaking conditions, it was carried out assays on synthetic must [12]. We decided to use this media to avoid the antimicrobial influence on yeast described to the hydroxycinnamic acids present in the natural grape must (mainly $p$-coumaric and ferulic acid) [33-35]. Thus, the viability of the spoilage strains B. bruxellensis LAMAP2480 and P. guilliermondii LAMAP3202 were assessed in mixed culture with S. cerevisiae EC1118 for 21 days (Figure 3).

The synthetic must was supplemented with $1 \mu \mathrm{g}$ of low-mass protein fraction obtained from C. intermedia supernatant, and then was inoculated using the spoilage yeasts. Posteriorly, it was inoculated with S. cerevisiae EC1118 (fermentation starter). As can be seen in Figure 3 (A, B), the growth of $S$. cerevisiae is not affected, demonstrating the harmlessness of the antifungal peptides against this yeast. In the case of the effect on B. bruxellensis, it was observed that its growth decreases in one magnitude order of difference compared to the control (3A), while in the case of P. guilliermondii L3202, minimal changes between the treatment and control were observed (Figure 3B). Despite having growth inhibition of P. guilliermondii in solid medium (Table 1), this effect was not seen in synthetic must, which can be related to a greater concentration of an antifungal compound, possibly requiring a greater concentration for this specie compared to B. bruxellensis. To date, there are no previous studies that assess the antifungal capacity of a compound of protein nature (AMP or killer toxin) on the growth of 
P. guilliermondii in mixed cultures with S. cerevisiae in synthetic wine must. Thus, it would be necessary to further study the action of $C$. intermedia peptides in winemaking conditions.

\section{A}

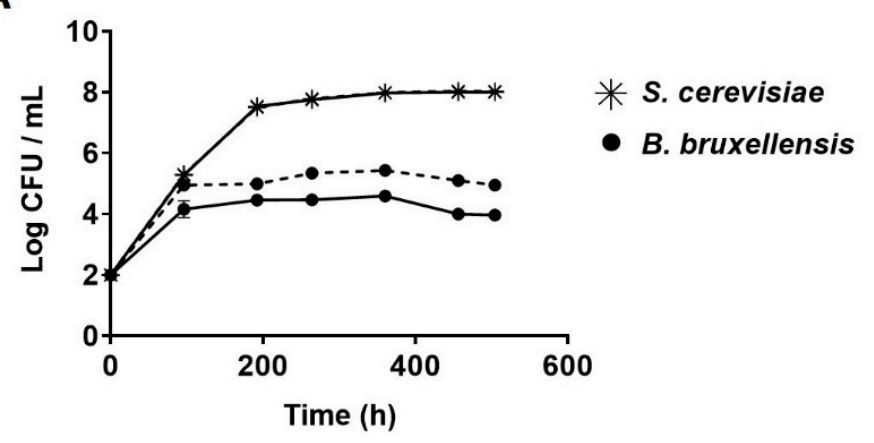

B

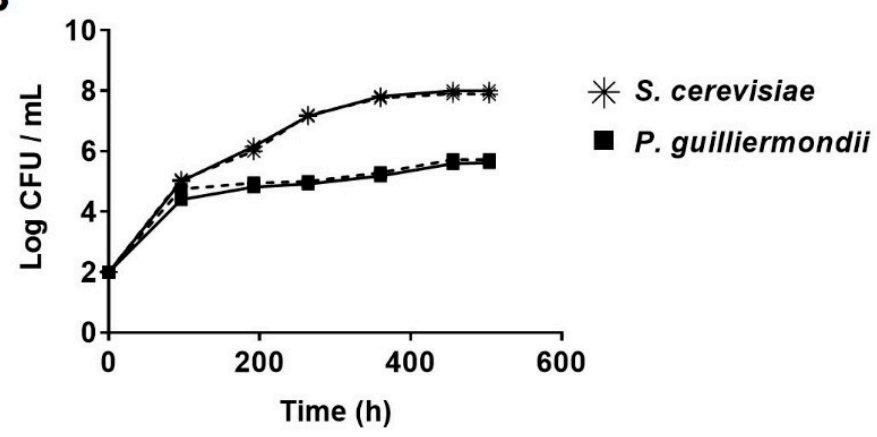

Figure 3. Antifungal activity of $1 \mu \mathrm{g}$ of low mass protein fraction (under $10 \mathrm{kDa}$ ) concentrated from C. intermedia L1790 supernatant (solid lines) used synthetic wine must. (A) S. cerevisiae with B. bruxellensis L2480 (B) S. cerevisiae with P. guilliermondii 3202. The controls (stripped lines) corresponds to the concentrated supernatant of S. cerevisiae BY4741 (not antifungal activity). All assays were performed in triplicate.

\section{Conclusions}

The antifungal supernatant obtained from de culture media of $C$. intermedia LAMAP1790 produces a continuous rise of oxygen reactive species (ROS) in B. bruxellensis, without trigger a significant effect on its membrane damage. This effect was totally avoided when the supernatant was treated with a proteolytic enzyme, proving that low mass peptides contained in this fraction are responsible for this effect. Herewith, C. intermedia L1790 showed antimicrobial effect on B. bruxellensis LAMAP2480, Pichia guilliermondii LAMAP3202, and LAMAP3203 when laboratory medium was used; however, similar effect was not observed when synthetic must was used. Therefore, it is necessary to identify the peptides with antifungal activity produced by C. intermedia LAMAP1790 and study how some enological factors ( $\mathrm{pH}$, ethanol, sugars, etc.) may affect their antifungal capacity. This will allow us to determine its possible technological application in the control of yeast contaminants in the wine industry.

Author Contributions: Conceptualization: R.P. and M.A.G.; Methodology: R.P. and M.A.G.; Formal analysis: R.P. and J.V.; Data analysis: R.P., J.V., and C.G.-P.; Supervision: M.A.G.; Writing-Original Draft: R.P., C.G.-P. and M.A.G.; Project Administration: M.A.G. All authors have read and agreed to the published version of the manuscript.

Funding: Rubén Peña was funded by the Comisión Nacional de Investigación Científica y Tecnológica CONICYT-PCHA/DoctoradoNacional/2013-21130439 Doctoral Fellowship. Camila G-Poblete was funded by Facultad Tecnológica Fellowship from Universidad de Santiago de Chile.

Conflicts of Interest: The authors hereby declare they do not have any conflict of interest associated to this work. 


\section{References}

1. Liu, Y.; Rousseaux, S.; Tourdot-Maréchal, R.; Sadoudi, M.; Gougeon, R.; Schmitt-Kopplin, P.; Alexandre, H. Wine microbiome: A dynamic world of microbial interactions. Crit. Rev. Food Sci. Nutr. 2017, 57, 856-873. [CrossRef] [PubMed]

2. Loureiro, V.; Malfeito-Ferreira, M. Spoilage yeasts in the wine industry. Int. J. Food Microbiol. 2003, 86, $23-50$. [CrossRef]

3. Oelofse, A.; Pretorius, I.S.; du Toit, M. Significance of Brettanomyces and Dekkera during Winemaking: A Synoptic Review. S. Afr. J. Enol. Vitic. 2008, 29, 128-144. [CrossRef]

4. Chatonnet, P.; Dubourdie, D.; Boidron, J.; Pons, M. The origin of ethylphenols in wines. J. Sci. Food Agric. 1992, 60, 165-178. [CrossRef]

5. Godoy, L.; García, V.; Peña, R.; Martínez, C.; Ganga, M.A. Identification of the Dekkera bruxellensis phenolic acid decarboxylase (PAD) gene responsible for wine spoilage. Food Control 2014, 45, 81-86. [CrossRef]

6. Dias, L.; Dias, S.; Sancho, T.; Stender, H.; Querol, A.; Malfeito-Ferreira, M.; Loureiro, V. Identification of yeasts isolated from wine-related environments and capable of producing 4-ethylphenol. Food Microbiol. 2003, 20, 567-574. [CrossRef]

7. Devalia, J.L.; Rusznak, C.; Herdman, M.J.; Trigg, C.J.; Davies, R.J.; Tarraf, H. Effect of nitrogen dioxide and sulphur dioxide on airway response of mild asthmatic patients to allergen inhalation. Lancet 1994, 344, 1668-1671. [CrossRef]

8. Enrique, M.; Marcos, J.F.; Yuste, M.; Martínez, M.; Vallés, S.; Manzanares, P. Antimicrobial action of synthetic peptides towards wine spoilage yeasts. Int. J. Food Microbiol. 2007, 118, 318-325. [CrossRef]

9. Enrique, M.; Marcos, J.F.; Yuste, M.; Martínez, M.; Vallés, S.; Manzanares, P. Inhibition of the wine spoilage yeast Dekkera bruxellensis by bovine lactoferrin-derived peptides. Int. J. Food Microbiol. 2008, 127, 229-234. [CrossRef]

10. Albergaria, H.; Francisco, D.; Gori, K.; Arneborg, N.; Gírio, F. Saccharomyces cerevisiae CCMI 885 secretes peptides that inhibit the growth of some non-Saccharomyces wine-related strains. Appl. Microbiol. Biotechnol. 2010, 86, 965-972. [CrossRef]

11. Branco, P.; Viana, T.; Albergaria, H.; Arneborg, N. Antimicrobial peptides (AMPs) produced by Saccharomyces cerevisiae induce alterations in the intracellular $\mathrm{pH}$, membrane permeability and culturability of Hanseniaspora guilliermondii cells. Int. J. Food Microbiol. 2015, 205, 112-118. [CrossRef]

12. Branco, P.; Francisco, D.; Monteiro, M.; Almeida, M.G.; Caldeira, J.; Arneborg, N.; Prista, C.; Albergaria, H. Antimicrobial properties and death-inducing mechanisms of saccharomycin, a biocide secreted by Saccharomyces cerevisiae. Appl. Microbiol. Biotechnol. 2017, 101, 159-171. [CrossRef]

13. Muñoz, A.; Harries, E.; Contreras-Valenzuela, A.; Carmona, L.; Read, N.D.; Marcos, J.F. Two Functional Motifs Define the Interaction, Internalization and Toxicity of the Cell-Penetrating Antifungal Peptide PAF26 on Fungal Cells. PLoS ONE 2013, 8, e54813. [CrossRef]

14. Muñoz, A.; Gandía, M.; Harries, E.; Carmona, L.; Read, N.D.; Marcos, J.F. Understanding the mechanism of action of cell-penetrating antifungal peptides using the rationally designed hexapeptide PAF26 as a model. Fungal Biol. Rev. 2013, 26, 146-155. [CrossRef]

15. Zhang, L.; Gallo, R.L. Antimicrobial peptides. Curr. Biol. 2016, 26, R14-R19. [CrossRef]

16. Peña, R.; Ganga, M.A. Novel antimicrobial peptides produced by Candida intermedia LAMAP1790 active against the wine-spoilage yeast Brettanomyces bruxellensis. Antonie van Leeuwenhoek 2018, 9. [CrossRef]

17. Peña, R.; Chávez, R.; Rodríguez, A.; Ganga, M.A. A Control Alternative for the Hidden Enemy in the Wine Cellar. Fermentation 2019, 5, 25. [CrossRef]

18. Ganga, M.A.; Martínez, C. Effect of wine yeast monoculture practice on the biodiversity of non-Saccharomyces yeasts. J. Appl. Microbiol. 2004, 96, 76-83. [CrossRef]

19. Valdes, J.; Tapia, P.; Cepeda, V.; Varela, J.; Godoy, L.; Cubillos, F.A.; Silva, E.; Martinez, C.; Ganga, M.A. Draft genome sequence and transcriptome analysis of the wine spoilage yeast Dekkera bruxellensis LAMAP2480 provides insights into genetic diversity, metabolism and survival. FEMS Microbiol. Lett. 2014, 361, 104-106. [CrossRef]

20. Sangorrín, M.P.; García, V.; Lopes, C.A.; Sáez, J.S.; Martínez, C.; Ganga, M.A. Molecular and physiological comparison of spoilage wine yeasts. J. Appl. Microbiol. 2013, 114, 1066-1074. [CrossRef] 
21. Roostita, L.B.; Fleet, G.H.; Wendry, S.P.; Apon, Z.M.; Gemilang, L.U. Determination of yeasts antimicrobial activity in milk and meat products. Adv. J. Food Sci. Technol. 2011, 3, 442-445.

22. Kaiserer, L.; Oberparleiter, C.; Weiler-Görz, R.; Burgstaller, W.; Leiter, E.; Marx, F. Characterization of the Penicillium chrysogenum antifungal protein PAF. Arch. Microbiol. 2003, 180, 204-210. [CrossRef] [PubMed]

23. Villalba, M.L.; Susana Sáez, J.; del Monaco, S.; Lopes, C.A.; Sangorrín, M.P. TdKT, a new killer toxin produced by Torulaspora delbrueckii effective against wine spoilage yeasts. Int. J. Food Microbiol. 2016, 217, 94-100. [CrossRef] [PubMed]

24. Bradford, M.M. A rapid and sensitive method for the quantitation of microgram quantities of protein utilizing the principle of protein-dye binding. Anal. Biochem. 1976, 72, 248-254. [CrossRef]

25. Gutiérrez, A.; Chiva, R.; Sancho, M.; Beltran, G.; Arroyo-López, F.N.; Guillamon, J.M. Nitrogen requirements of commercial wine yeast strains during fermentation of a synthetic grape must. Food Microbiol. 2012, 31, 25-32. [CrossRef] [PubMed]

26. Coronado, P.; Aguilera, S.; Carmona, L.; Godoy, L.; Martínez, C.; Ganga, M.A. Comparison of the behaviour of Brettanomyces bruxellensis strain LAMAP L2480 growing in authentic and synthetic wines. Antonie van Leeuwenhoek 2015, 107, 1217-1223. [CrossRef] [PubMed]

27. Sáez, J.S.; Lopes, C.A.; Kirs, V.C.; Sangorrín, M.P. Enhanced volatile phenols in wine fermented with Saccharomyces cerevisiae and spoiled with Pichia guilliermondii and Dekkera bruxellensis. Lett. Appl. Microbiol. 2010, 51, 170-175. [CrossRef] [PubMed]

28. Harrington, B.J.; Hageage, G.J. your lab focus: Calcofluor White: A Review of its Uses and Applications in Clinical Mycology and Parasitology. Lab. Med. 2003, 34, 361-367. [CrossRef]

29. Suzuki, S.W.; Onodera, J.; Ohsumi, Y. Starvation induced cell death in autophagy-defective yeast mutants is caused by mitochondria dysfunction. PLoS ONE 2011, 6, e17412. [CrossRef]

30. Reggiori, F.; Klionsky, D.J. Autophagic processes in yeast: Mechanism, machinery and regulation. Genetics 2013, 194, 341-361. [CrossRef]

31. López-García, B.; Gandía, M.; Muñoz, A.; Carmona, L.; Marcos, J.F. A genomic approach highlights common and diverse effects and determinants of susceptibility on the yeast Saccharomyces cerevisiae exposed to distinct antimicrobial peptides. BMC Microbiol. 2010, 10. [CrossRef]

32. Lopes, C.A.; Sangorrín, M.P. Optimization of killer assays for yeast selection protocols. Rev. Argent. Microbiol. 2010, 42, 298-306. [CrossRef]

33. Stead, D. The effect of hydroxycinnamic acids and potassium sorbate on the growth of 11 strains of spoilage yeasts. J. Appl. Bacteriol. 1995, 78, 82-87. [CrossRef]

34. Harris, V.; Jiranek, V.; Ford, C.M.; Grbin, P.R. Inhibitory effect of hydroxycinnamic acids on Dekkera spp. Appl. Microbiol. Biotechnol. 2010, 86, 721-729. [CrossRef]

35. Lentz, M.; Harris, C. Analysis of Growth Inhibition and Metabolism of Hydroxycinnamic Acids by Brewing and Spoilage Strains of Brettanomyces Yeast. Foods 2015, 4, 581-593. [CrossRef] 